\title{
Hepatoprotective Effect of Citrus limon Fruit Extract against Carbofuran Induced Toxicity in Wistar Rats
}

\author{
Sunil Kumar Jaiswal, ${ }^{1}$ Vivek K. Gupta, ${ }^{1}$ Nikhat J. Siddiqi, ${ }^{2}$ \\ Ravi S. Pandey, ${ }^{3}$ and Bechan Sharma ${ }^{1}$ \\ ${ }^{1}$ Department of Biochemistry, University of Allahabad, Allahabad 211002, India \\ ${ }^{2}$ Department of Biochemistry, King Saud University, Riyadh, Saudi Arabia \\ ${ }^{3}$ Department of Zoology, University of Allahabad, Allahabad 211002, India \\ Correspondence should be addressed to Bechan Sharma; sharmabi@yahoo.com
}

Received 26 August 2015; Accepted 4 October 2015

Academic Editor: Yinguang Chen

Copyright (C) 2015 Sunil Kumar Jaiswal et al. This is an open access article distributed under the Creative Commons Attribution License, which permits unrestricted use, distribution, and reproduction in any medium, provided the original work is properly cited.

Carbofuran (2,3-dihydro-2,2-dimethyl-7-benzofuranol methylcarbamate), is known to induce oxidative stress and to cause inhibition of acetylcholinesterase activity. The present work was envisaged to evaluate the effect of carbofuran on redox indices and its interactions with hepatic markers in rat. The ameliorating effect of Citrus limon fruit extract on carbofuran induced toxicity was also monitored. The results indicated that carbofuran treatment caused significant alterations in the levels of activities of AST, ALT, and LDH in liver tissues and serum. The levels of enzymatic oxidative stress markers such as SOD and catalase and nonenzymatic redox molecules such as total thiol, GSH, and protein thiol also showed significant perturbations in rat liver due to carbofuran treatment. The administration of Citrus limon fruit extract, however, was able to markedly ameliorate the toxicity of carbofuran by protecting the levels of aforesaid biomarkers to near normal levels. The ameliorative effect of Citrus limon fruit extract may be due to the presence of different antioxidants in it which may neutralize the ROS and RNS generated in the body tissue due to pesticide stress. These results suggested that Citrus limon fruit extract may be utilized as a potential supplement in proper management of pesticide intoxication in association with relevant therapeutics.

\section{Introduction}

Pesticides are the chemical or biological agents commonly used worldwide for preventing, destroying, or mitigating any pest in order to protect the agricultural crops and increase the yield. The indiscriminate applications of these substances, however, may lead to number of toxicological consequences to the environmental components [1]. The commonly used organochlorine, organocarbamate, and organophosphate pesticides are known to accumulate both in biotic and in abiotic systems posing threat to the environment in general and mammalian systems in particular [2,3]. The organochlorine pesticides such as lindane ( $\gamma$-hexachlorocyclohexane) induce hyperexcitability [4] by both stimulating the synaptic transmission and suppressing the GABA-activated chloride current by interacting with the receptor GABA-chloride channel complex [5]. Organophosphate (OP) and organocarbamate
(OC) are known acetylcholinesterase inhibitors (AChE). The OPs phosphorylate covalently AChE while OCs reversibly carbamylate the $-\mathrm{OH}$ group of serine residue present at the active site of AChE [6,7]. Since carbamylation of AChE by OCs is recovered in short time compared to the phosphorylation by the organophosphorus pesticides [8], the former one was found safer in application than the latter. In addition, the relatively less environmentally persistent and more degradable nature of OCs exerts lesser toxicity into nontarget organisms as compared to other pesticides.

However, with the disproportionate and unregulated applications and the lack of selectivity, OCs may cause serious health hazards to humans as well as animals due to accidental, environmental, and occupational exposures $[9,10]$. It is well reported that carbofuran may cause toxicity to the vital organs of the mammalian systems such as brain, liver, heart, and skeletal muscles [11-13]. Like other pesticides, 
carbofuran exposure is also known to cause oxidative injury via perturbations in the structure and functions of cellular membranes $[14,15]$.

Major detoxification of various drugs and chemicals occurs in the liver, and the intermediate metabolites get accumulated in the liver cells, which may be responsible for oxidative stress into hepatocytes [16]. The chronic and acute exposure of carbofuran has been reported to cause perturbations into the levels of enzymes such as aminotransaminases, glutamate dehydrogenase, and glycogen phosphorylase (a and b) as well as other biomolecules including protein, amino acids, ammonia, and glycogen from rat liver and muscles [14]. The acute intoxication of carbofuran may cause alterations in the levels of globular protein, triglycerides, cholesterol, and depletion of adenosine triphosphate (ATP) and phosphocreatine (PCr) in rat liver and serum [17].

The antioxidant compounds follow one or more than one type of mechanisms to reduce the hazards of oxidative stress induced in a living system due to exposure of any physical or chemical agents. Generally these molecules scavenge free radicals by forming complexes with prooxidants and thereby quenching the free radical species. In the biological systems, the antioxidants are of two types: nonenzymatic molecules like glutathione and vitamins $\mathrm{C}, \mathrm{D}$, and $\mathrm{E}$ and the enzymatic indices such as SOD, catalase, and GST [18].

Citrus limon (lemon) belongs to the family Rutaceae, which comprises 150 genera with approximately 2000 species containing antibacterial, antiviral, antioxidant, antifungal, analgesic, and anti-inflammatory properties [19]. The compounds which have properties to mimic the oxidation of lipid or other biomolecules by arresting the initiation or propagation of oxidative chain reactions are included in the list of antioxidants [18]. C. limon fruit extract contains numerous active ingredients such as total flavonoids (900 $\mathrm{mg} \mathrm{L}^{-1}$ ) (flavones, flavanones), pectins (500 $\left.\mathrm{mg} \mathrm{L}^{-1}\right)$, ascorbic acid (470 $\left.\mathrm{mg} \mathrm{L}^{-1}\right)$, and hesperidin (200 $\left.\mathrm{mg} \mathrm{L}^{-1}\right)$ [20]. The epidemiological studies have shown that the diet with high fruits and vegetables has potential to protect the human body against Reactive Oxygen Species mediated damage. In the recent years the investigations have indicated that the antioxidant properties of the fruits and vegetables are due to presence of high amounts of known antioxidants such as polyphenols, vitamin $\mathrm{C}$, vitamin $\mathrm{E}, \beta$-carotene, and lycopene [21]. Besides possessing antioxidant properties, ascorbic acid (vitamin C) also plays a key role in collagen biosynthesis, iron absorption, immune response activation, wound healing, and osteogenesis [22]. Flavonoids are nonnutrients but act as antioxidant compounds and help reduce the load of free radicals and/or boost the endogenous antioxidant defense system [23].

Earlier reports from our laboratory have indicated that carbofuran at sublethal concentrations may induce oxidative stress in rats $[15,24,25]$. The pesticide induced free radicals mediated toxicity, however, may be ameliorated by introduction of extracts from some traditional Indian medicinal plants $[17,24-26]$. The aim of the present study was to evaluate the hepatoprotective effect of $C$. limon fruit extract against carbofuran induced toxicity in rats.

\section{Materials and Methods}

2.1. Chemicals. Carbofuran, a technical grade, $99.6 \%$ pure in powered form, was a gift of Rallis India Limited (Bangalore, India). Edible groundnut oil and C. limon fruit were purchased from the local market. Pyrogallol, reduced glutathione (GSH), 1-chloro-2,4-dinitrobenzene (CDNB), acetylthiocholine-iodide (ATI), 3,5-dithionitrobenzoic acid (DTNB), and bovine serum albumin (BSA) were purchased from Sisco Research Laboratories (Mumbai, India). All other chemicals used were of analytical grade.

2.2. Animals. Twenty male Wister rats weighing 100 to $120 \mathrm{~g}$ and aged 7 to 8 weeks were purchased from Central Drug Research Institute, Lucknow, India. All animals were housed in polypropylene cage under ambient environmental conditions. Animals were fed standard pellet diet (Dayal Industries, Lucknow, India) along with water ad libitum. The protocols for maintenance, care, and treatment of animals were followed as per the provisions laid down by the Institutional Ethical Committee.

2.3. Preparation of Citrus limon Fruit Extract. C. limon fruit extract was prepared by squeezing the freshly washed lemons and filtering it using muslin cloth. The water content of $C$. limon fruit extract was $89 \%, \mathrm{pH} 2.0$, and total soluble solid was $0.25 \%$. Among the vitamins present in the C. limon fruit extract, vitamin C contributed to maximum extent (35\%).

2.4. Experimental Design. Twenty male Wistar rats were divided into four groups and each group contained five animals.

Control. Animals received only $0.5 \mathrm{~mL}$ groundnut oil three times at the interval of $24 \mathrm{~h}$.

The 5 animals of the first group received CF at a dose of $20 \%$ of $\mathrm{LD}_{50}$, that is, $1.6 \mathrm{mg} \mathrm{CF} \mathrm{Kg}{ }^{-1}$ body weight (bw) in $0.5 \mathrm{~mL}$ groundnut oil orally three times using gavages at an interval of $24 \mathrm{~h}$.

C. limon Fruit Extract (Citrus). Each animal received $0.5 \mathrm{~mL}$ Citrus limon fruit extract three times at the interval of $24 \mathrm{~h}$.

C. limon Fruit Extract $+20 \%$ CF (Citrus $+20 \%$ CF). Animals received $0.5 \mathrm{~mL} \mathrm{C}$. limon fruit extract just $30 \mathrm{~min}$ before receiving $\mathrm{CF}$ in $0.5 \mathrm{~mL}$ groundnut oil three times at the interval of $24 \mathrm{~h}$.

At the end of the treatment, all animals were anaesthetized with mild chloroform and sacrificed.

2.5. Preparation of Rat Liver Homogenate for AChE Activity. The liver from the sacrificed animal was removed and perfused with ice-cold saline $(0.9 \% \mathrm{NaCl}, \mathrm{w} / \mathrm{v})$, blotted dry, and weighed. For AChE activity measurement, the liver tissues were homogenized $(10 \%, \mathrm{w} / \mathrm{v})$ in $50 \mathrm{mM}$ phosphate buffer, $\mathrm{pH} 8.0$ containing $0.2 \%$ Triton $\mathrm{X}-100$ at $4^{\circ} \mathrm{C}$ using a Remi homogenizer with pestle coated with Teflon. The remaining liver tissues were stored at $-80^{\circ} \mathrm{C}$. The homogenate was kept in the capped centrifuge tubes for $30 \mathrm{~min}$ at $4^{\circ} \mathrm{C}$ 
with intermittent gentle shaking and then centrifuged at $10,000 \mathrm{~g}$ for $30 \mathrm{~min}$ at $4^{\circ} \mathrm{C}$. The supernatant was collected in precooled Eppendorf tubes and the pellet was discarded. This preparation was used for both the assay of AChE activity and protein estimation.

2.6. Preparation of Rat Liver Homogenate in Sucrose Solution. The liver homogenate $(10 \%, \mathrm{w} / \mathrm{v})$ was prepared in $0.25 \mathrm{M}$ sucrose solution and centrifuged at $9000 \times \mathrm{g}$ for $30 \mathrm{~min}$ at $4-$ $6^{\circ} \mathrm{C}$. The supernatants were separated by gentle decantation of centrifuged homogenates of tissues and used for various biochemical estimations.

2.7. Preparation of Serum from Rat Blood. About $5 \mathrm{~mL}$ blood was collected from each animal in sterile centrifuged tube. The coagulated blood was centrifuged at $1000 \times \mathrm{g}$ at $4^{\circ} \mathrm{C}$ for $10 \mathrm{~min}$ and the serum was collected as supernatant.

\subsection{Estimation of Levels of Certain Biochemical Indices}

2.8.1. Assay of AChE Activity. The activity of acetylcholinesterase (AChE, EC 3.1.1.7) was assayed by the method of Ellman et al. (1961) [27]. The reaction mixture $(3 \mathrm{~mL})$ in quartz cuvette $(1 \mathrm{~cm}$ light path length) contained $0.5 \mathrm{mM}$ acetylthiocholine-iodide (ATI), $0.5 \mathrm{mM} \mathrm{DTNB}$, and $50 \mathrm{mM}$ phosphate buffer, $\mathrm{pH}$ 7.6. The change in optical density was measured at $412 \mathrm{~nm}$ for $3 \mathrm{~min}$. The specific activity of enzyme was presented in $\mu$ mole $\mathrm{min}^{-1} \mathrm{mg}^{-1}$ protein using extinction coefficient, $13.6 \times 10^{3} \mathrm{M}^{-1} \mathrm{~cm}^{-1}$. Assays were performed on UV-Visible double beam spectrophotometer (Spectroscan UV 2700). The reaction mixture without enzyme protein served as a control in this assay.

2.8.2. Assays to Determine Activities of Lactate Dehydrogenase (LDH), Aspartate Aminotransferase (AST), and Alanine Aminotransferase (ALT). The activity of $\mathrm{LDH}$ was assayed by the method of Horecker and Kornberg [28] in serum and the cell-free extract of liver. The reaction was performed in quartz cuvette. In brief, the total reaction mixture $(3 \mathrm{~mL})$ contained $1 \mathrm{~mL} 0.2 \mathrm{M}$ Tris- $\mathrm{HCl}$ buffer (pH 7.4), $0.15 \mathrm{~mL} 0.1 \mathrm{M} \mathrm{KCl}$, $0.15 \mathrm{~mL} 50 \mathrm{mM}$ sodium pyruvate, $0.20 \mathrm{~mL} 2.4 \mathrm{mM} \mathrm{NADH}$, suitably diluted enzyme protein, and distilled water. The enzyme activity was monitored as decrease in the absorbance at $340 \mathrm{~nm}$ for $3 \mathrm{~min}$. The reaction mixture without enzyme protein served as a control in this assay system.

The activities of aspartate transaminase (AST, EC 2.6.1.1) and alanine transaminase (ALT, EC 2.6.1.10) in the serum and cell-free extract of liver were measured by using the method of Reitman and Frankel (1957) [29]. The suitable amount of protein of serum or cell-free extract of liver was incubated in $0.25 \mathrm{~mL}$ of substrate (aspartate and $\alpha$ ketoglutarate for AST; alanine and $\alpha$-ketoglutarate for ALT, in phosphate buffer, $\mathrm{pH} 7.4$ ) for $30 \mathrm{~min}$. $0.25 \mathrm{~mL}$ of DNPH (2,4-dinitrophenylhydrazine) was used to stop the reaction and kept for $20 \mathrm{~min}$ at room temperature. After incubation, $2.5 \mathrm{~mL}$ of $0.4 \mathrm{~N} \mathrm{NaOH}$ was added and gently vortexed. The optical density was monitored at $510 \mathrm{~nm}$. The reaction mixture without enzyme protein served as a control in each case.
2.8.3. Estimation of Serum Lipids. Spectrophotometric analysis of serum total cholesterol (TC) and high density lipoprotein (HDL) in serum were measured at $560 \mathrm{~nm}$ by the method of Zlatkis et al. [30]. Cholesterol was used as standard to determine the value of unknown sample. For HDL measurement the supernatant of serum treated with phosphotungstic acid and magnesium chloride [31] was used and the unknown values of HDL were determined according to the method of Zlatkis et al. [30].

2.8.4. Measurement of TBARS Levels. Lipid peroxidation was measured in the cytosolic fraction of hepatic tissues by following the method of Niehaus and Samuelsson (1968) [32] and the results were expressed as nmol $\mathrm{MDA} / \mathrm{mg}$ protein using the extinction coefficient of $1.56 \times 10^{5} \mathrm{M}^{-1} \mathrm{~cm}^{-1}$.

2.8.5. Estimation of the Activities of Antioxidant Enzymes. The activity of superoxide dismutase (SOD, EC 1.15.1.1) was measured by following the method of S. Marklund and G. Marklund (1974) [33]. It is a spectrophotometric measurement of optical density of colored complex involving pyrogallol autooxidation at $412 \mathrm{~nm}$ for $3 \mathrm{~min}$ at the interval of $30 \mathrm{sec}$ with or without the enzyme protein. One unit of the enzyme activity was expressed as 50\% inhibition of autooxidation of pyrogallol per min.

The catalase (CAT, EC 1.11.1.6) activity was measured according to the method of Beers and Sizer [34] by measuring the decrease in the absorbance for $\mathrm{H}_{2} \mathrm{O}_{2}$ consumption at $240 \mathrm{~nm}$ at the interval of $30 \mathrm{sec}$ for $3 \mathrm{~min}$. One unit of CAT activity was defined as micromoles of $\mathrm{H}_{2} \mathrm{O}_{2}$ decomposed per min using molar extinction coefficient of $\mathrm{H}_{2} \mathrm{O}_{2}$ $\left(43.6 \mathrm{M}^{-1} \mathrm{~cm}^{-1}\right)$.

The activity of glutathione-S-transferase (GST, EC 2.5.1.18) was measured according to Habig et al. [35]. The change in absorbance was recorded spectrophotometrically at $340 \mathrm{~nm}$ for $3 \mathrm{~min}$ at the interval of $30 \mathrm{sec}$ and the results were expressed as $\mu$ mole $\mathrm{mL}^{-1} \mathrm{~min}^{-1} \mathrm{mg}^{-1}$ protein.

2.8.6. Determination of the Levels of Nonenzymatic Antioxidants. The total thiol content in the hepatic tissues was determined by the method of Ellman [36] modified by Sedlak and Lindsay [37]. The intensity of yellow color was measured at $412 \mathrm{~nm}$. In $2.0 \mathrm{~mL}$ microcentrifuge tube the reaction mixture $(1 \mathrm{~mL})$ contains $105 \mu \mathrm{L} 0.2 \mathrm{M}$ Tris- $\mathrm{HCl}$ buffer $(\mathrm{pH}$ 8.2), $20 \mu \mathrm{L} \mathrm{0.01} \mathrm{M} \mathrm{DTNB,} \mathrm{and} 825 \mu \mathrm{L}$ absolute methanol and $50 \mu \mathrm{L}$ liver homogenate was mixed and left for $15 \mathrm{~min}$ with intermittent shaking and centrifuged at $800 \times \mathrm{g}$ for $15 \mathrm{~min}$. The optical density of the supernatant was recorded. The results were expressed as $\mu \mathrm{g} \mathrm{mg}^{-1}$ protein.

The GSH content in liver tissues was determined by the method of Ellman [36]. Briefly, the $250 \mu \mathrm{L}$ deproteinized supernatant of liver homogenate was mixed with $100 \mu \mathrm{L}$ of $6 \mathrm{mM}$ DTNB, $300 \mu \mathrm{L}$ of $200 \mathrm{mM}$ phosphate buffer, $\mathrm{pH} 8.0$, and $50 \mu \mathrm{L}$ of $300 \mathrm{mM} \mathrm{NaOH}$. The optical density of the reaction mixture was measured at $412 \mathrm{~nm}$. The difference between the values for total thiols and low molecular weight thiols (GSH) has been considered for the calculation of protein thiols. All the values were expressed as $\mu \mathrm{g} \mathrm{mg}^{-1}$ protein. 


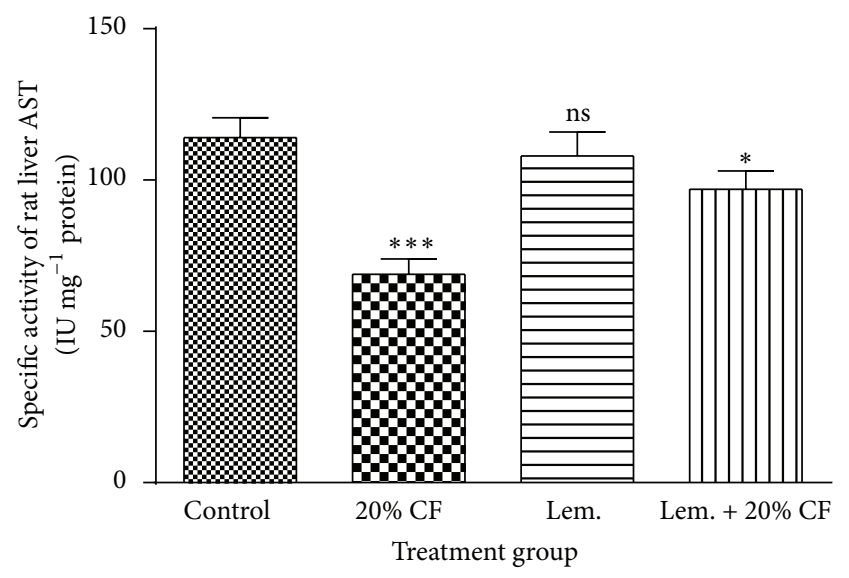

FIGURE 1: Effect of CF on the activity of AST in liver of rat and amelioration by $C$. limon fruit extract. Control: control group treated with $0.5 \mathrm{~mL}$ groundnut oil; $20 \%$ CF: three subacute oral doses $\left(1.6 \mathrm{mg} \mathrm{Kg}^{-1}\right.$ bwt equivalent to $20 \% \mathrm{LD}_{50}$ ) of $\mathrm{CF}$. C. limon: the rats treated with $0.5 \mathrm{~mL}$ C. limon fruit extract three times at the intervals of $24 \mathrm{~h}$. C. limon $+20 \%$ CF refer to the experimental animals group which received $0.5 \mathrm{~mL}$ lemon juice $30 \mathrm{~min}$ prior to the treatment of rats with $\mathrm{CF}\left(1.6 \mathrm{mg} \mathrm{Kg}{ }^{-1} \mathrm{bwt}\right)$. All the treatments were given as three-time oral doses at the interval of $24 \mathrm{~h}$ and experiments were carried out up to three days. The animals were sacrificed after $24 \mathrm{~h}$ from the last dose of treatment. AST activity was determined as described in Materials and Methods. The unit of enzyme activity was expressed as IU mg ${ }^{-1}$ protein. The values were expressed as Mean $\pm \mathrm{SD} ; n=5$, where $n$ is number of determinations. The signs $*$ and $* * *$ indicate the data significant at $p<0.05$ and $p<0.005$, respectively, as compared to the control group.

2.8.7. Determination of Total Protein in the Liver and Serum. The protein content present in different samples was measured according to the method of Lowry et al. [38] using bovine serum albumin (BSA) as a standard.

2.8.8. Statistical Analysis. Data are presented as Mean \pm standard deviation using GraphPad Prism version 5.01 for Windows, GraphPad Software, San Diego, California, USA. Data were analyzed using one-way analysis of variance (ANOVA). Different groups were compared using Bonferroni’s Multiple Comparison Test and considered significant at $p \leq 0.05$.

\section{Results}

3.1. Effect of Carbofuran on Hepatic Markers in Serum and Tissues and Amelioration by Citrus limon Fruit Extract. The exposure of rats to sublethal concentration of carbofuran (1.6 $\mathrm{mg} \mathrm{Kg}^{-1}$ body weight; $20 \%$ of $\mathrm{LD}_{50}$ value) three times at each interval of $24 \mathrm{~h}$ up to 3 days showed drastic perturbations in the levels of hepatic markers (AST, ALT, and LDH) in the rat liver and the serum. The data presented in Figures 1, 2 , and 3 reflected that carbofuran caused significant decrease in the activities of these marker enzymes, the values being 39.5, 41.82, and $51.28 \%$ for AST (Figure 1), ALT (Figure 2), and $\mathrm{LDH}$ (Figure 3), respectively, in liver tissues. In contrast, the results presented in Figures 4, 5, and 6 showed significant increase in the activities of these enzymes by $94.90,111.85$, and

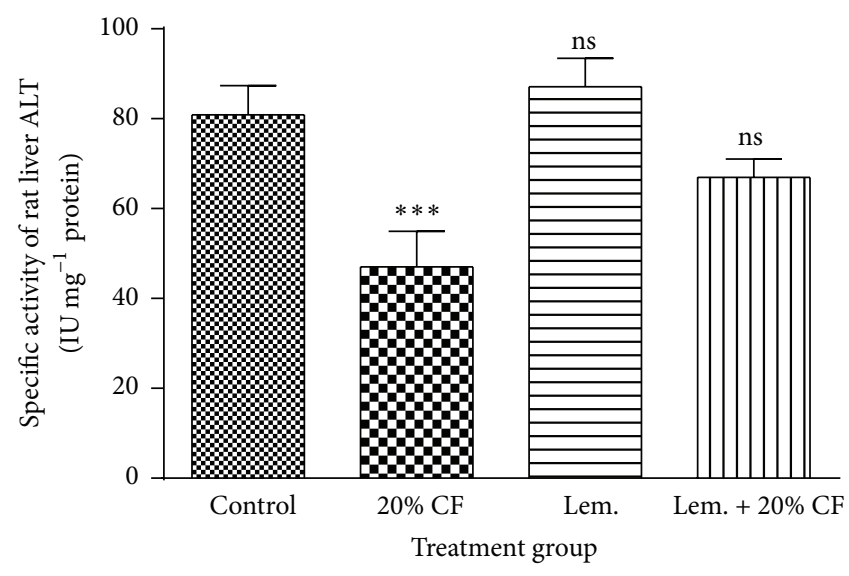

FIgURE 2: Effect of CF on the activity of ALT in liver of rat and amelioration by C. limon fruit extract. Control: control group treated with $0.5 \mathrm{~mL}$ groundnut oil; $20 \% \mathrm{CF}$ : three subacute oral doses (1.6 $\mathrm{mg} \mathrm{Kg}^{-1}$ bwt equivalent to $20 \% \mathrm{LD}_{50}$ ) of CF. C. limon: the rats treated with $0.5 \mathrm{~mL}$ C. limon fruit extract three times at the intervals of $24 \mathrm{~h}$. C. limon $+20 \% \mathrm{CF}$ refer to the experimental animals group which received $0.5 \mathrm{~mL} \mathrm{C}$. limon fruit extract $30 \mathrm{~min}$ prior to the treatment of rats with $\mathrm{CF}\left(1.6 \mathrm{mg} \mathrm{Kg}^{-1}\right.$ bwt $)$. All the treatments were given as three-time oral doses at the interval of $24 \mathrm{~h}$ and experiments were carried out up to three days. The animals were sacrificed after $24 \mathrm{~h}$ from the last dose of treatment. ALT activity was determined as described in Materials and Methods. The unit of enzyme activity was expressed as IU mg ${ }^{-1}$ protein. The values were expressed as Mean $\pm \mathrm{SD} ; n=5$, where $n$ is number of determinations. The $\operatorname{sign} * * *$ indicates the data significant at $p<0.005$ as compared to the control group.

$85.11 \%$, respectively, for AST (Figure 4), ALT (Figure 5), and $\mathrm{LDH}$ (Figure 6) in the serum of rat treated with carbofuran as compared to the control group.

Upon pretreatment of rats with lemon juice followed by exposure to carbofuran, the significant recovery in the levels of activities of these three key enzymes (AST, ALT, and LDH) was observed both in the tissues and in the serum of rats as the values recorded under this experimental condition were quite close to that of the control group (Figures 1-6). The extent of recovery, however, varied from tissues to serum.

3.2. Effect of Carbofuran and C. limon Fruit Extract on the Levels of Total Cholesterol and HDL in Serum. The results presented in Figures 7 and 8 reflected the alterations in the levels of total cholesterol and HDL in the serum due to carbofuran treatment. The level of total cholesterol was significantly $(p<0.05)$ elevated $(31 \%)$ whereas the level of HDL got decreased by $39.2 \%$ upon carbofuran treatment. The administration of $C$. limon fruit extract prior to carbofuran treatment, however, resulted in significant recovery in the levels of total cholesterol (Figure 7) and HDL (Figure 8) as the values recorded under this experimental condition were found to be quite close to that of the control group.

3.3. Effect of Carbofuran on the Antioxidant Defense Indices in the Rat Liver and Amelioration by $C$. limon Fruit Extract. Carbofuran administration caused significant $(p<0.001)$ 


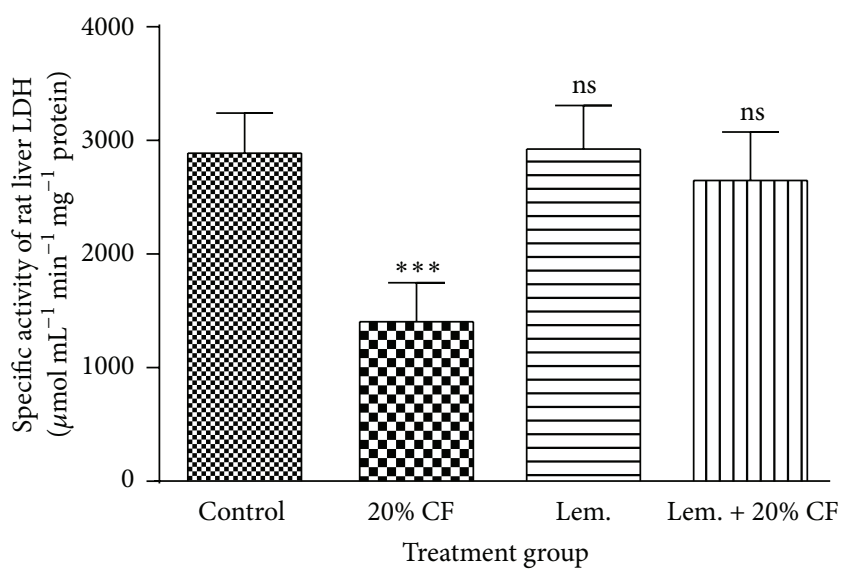

FIGURE 3: Effect of CF on the activity of LDH in liver of rat and amelioration by $C$. limon fruit extract. Control: control group treated with $0.5 \mathrm{~mL}$ groundnut oil; $20 \%$ CF: three subacute oral doses $\left(1.6 \mathrm{mg} \mathrm{Kg}^{-1}\right.$ bwt equivalent to $20 \% \mathrm{LD}_{50}$ ) of $\mathrm{CF}$. C. limon: the rats treated with $0.5 \mathrm{~mL} \mathrm{C}$. limon fruit extract three times at the intervals of 24 hours. C. limon $+20 \% \mathrm{CF}$ refer to the experimental animals group which received $0.5 \mathrm{~mL}$ lemon juice $30 \mathrm{~min}$ prior to the treatment of rats with $\mathrm{CF}\left(1.6 \mathrm{mg} \mathrm{Kg}^{-1} \mathrm{bwt}\right)$. All the treatments were given as three-time oral doses at the interval of $24 \mathrm{~h}$ and experiments were carried out up to three days. The animals were sacrificed after $24 \mathrm{~h}$ from the last dose of treatment. LDH activity was determined as described in Materials and Methods. The values were expressed as Mean $\pm \mathrm{SD} ; n=5$, where $n$ is number of determinations. The sign $(* * *)$ indicates values significantly different from control at $p<0.005$.

increase (60.6\%) in the levels of MDA in rat liver (Figure 9). The levels of nonenzymatic antioxidant molecules such as total thiol (Figure 10), GSH (Figure 11), and protein thiol (Figure 12) were found to be significantly increased upon carbofuran treatment, the values being 116.4, 66.86, and $153.19 \%$ for total thiol, GSH, and protein thiol, respectively. When the animals were pretreated with $C$. limon fruit extract followed by carbofuran exposure, the levels of these antioxidant molecules reached near normal values (Figures 10,11 , and 12).

\subsection{Effect of Carbofuran on the Activities of Antioxidant} Enzymes in Rat Liver and Amelioration by C. limon Fruit Extract. The data presented in Table 1 demonstrated that carbofuran treatment caused marked reduction in the activities of antioxidant enzymes (GST, SOD, and CAT) in the rat liver. The activities of GST, SOD, and catalase were found to be significantly ( $p \leq 0.05$ ) reduced by 42,38 , and $37.6 \%$, respectively, in the carbofuran treated rat. However, the pretreatment of the experimental animals with the C. limon fruit extract, however, reflected significant recovery in the activities of these enzymes as their values recorded under this experimental condition registered quite close to that of the control group.

3.5. Effect of Carbofuran on the Activity of Acetylcholinesterase (AChE) in Rat Liver and Amelioration by C. limon Fruit Extract. The data presented in Table 1 indicated that

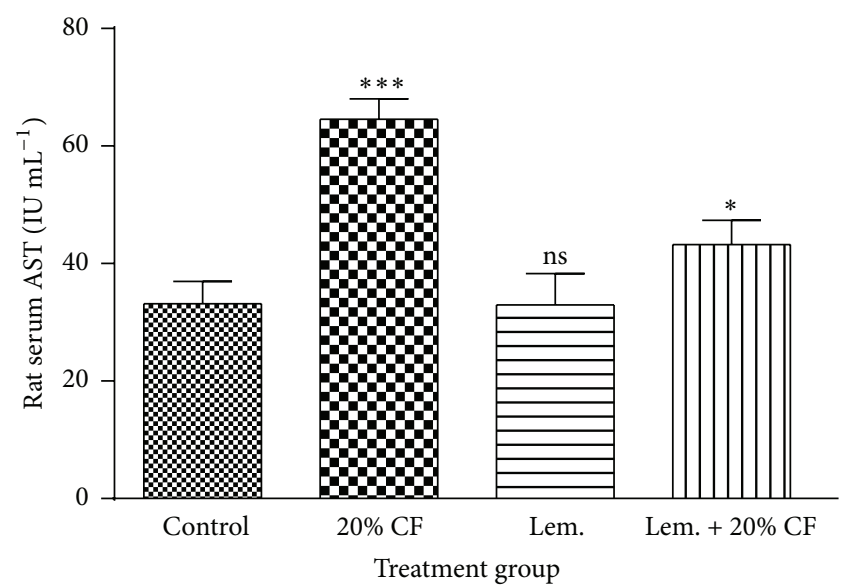

FIGURE 4: Effect of CF on the activity of AST in serum of rat and amelioration by C. limon fruit extract. Control: control group treated with $0.5 \mathrm{~mL}$ groundnut oil; $20 \% \mathrm{CF}$ : three subacute oral doses (1.6 mg Kg ${ }^{-1}$ bwt equivalent to $20 \% \mathrm{LD}_{50}$ ) of CF. Citrus: the rats treated with $0.5 \mathrm{~mL}$ C. limon fruit extract three times at the intervals of 24 hours. Citrus $+20 \%$ CF refer to the experimental animals group which received $0.5 \mathrm{~mL} \mathrm{C}$. limon fruit extract $30 \mathrm{~min}$ prior to the treatment of rats with $\mathrm{CF}\left(1.6 \mathrm{mg} \mathrm{Kg}^{-1} \mathrm{bwt}\right)$. All the treatments were given as three-time oral doses at the interval of $24 \mathrm{~h}$ and experiments were carried out up to three days. The animals were sacrificed after $24 \mathrm{~h}$ from the last dose of treatment. AST activity was determined as described in Materials and Methods. The unit of enzyme activity was expressed as IU $\mathrm{mL}^{-1}$. The values were expressed as Mean $\pm \mathrm{SD}$; $n=5$, where $n$ is number of determinations. The signs $*$ and $* * *$ indicate the data significant at $p<0.05$ and $p<0.005$, respectively, as compared to the control group.

carbofuran treatment caused significant $(p<0.001)$ inhibition in the activity of AChE (38.2\%) as compared to the control group. This inhibition was overcome to near normal level by the administration of $C$. limon fruit extract in rats.

\section{Discussion}

The present work was designed to study the ameliorative effect of C. limon fruit extract against carbofuran induced hepatotoxicity. Carbofuran is hydrophobic in nature and the earlier studies with hydrophobic pesticides have experimentally shown the accumulation of pesticides in the phospholipid bilayers of the biological membrane [39]. The lipid-rich internal tissues together with body fat, skin, liver, kidney, ovaries, and elements of the central and peripheral nervous system possess pesticide accumulation properties [40, 41]. Metabolism of carbofuran occurs in the liver where metabolic intermediates including free radical species (FRS) are produced in high concentration which may cause generation of the oxidative stress in liver tissues [11]. The elevated MDA level in the present study due to carbofuran treatment is indicative of the liver damage by the oxidative stress. The elevated levels of AST, ALT, and LDH in the serum and the decreased levels of these parameters in the liver tissues indicated carbofuran induced damage of liver tissues. These results are in agreement with those reported by other workers with some different pesticides [42]. The animals when given 
TABLE 1: Effect of carbofuran on activities of antioxidative enzymes and AChE in the rat liver tissues as well as amelioration by C. limon fruit extract.

\begin{tabular}{lcccc}
\hline Parameters & Control & $20 \%$ CF & C. limon & C. limon + 20\% CF \\
\hline GST liver $^{\mathrm{a}}$ & $1735 \pm 306.3$ & $1005 \pm 112.9^{* * *}$ & $2006 \pm 197.9^{\mathrm{ns}}$ & $1488 \pm 127.4^{\mathrm{ns}}$ \\
SOD liver $^{\mathrm{b}}$ & $21.13 \pm 1.98$ & $12.93 \pm 2.67^{* * *}$ & $20.92 \pm 2.63^{\mathrm{ns}}$ & $17.26 \pm 1.93^{*}$ \\
Catalase liver $^{\mathrm{b}}$ & $5.65 \pm 0.85$ & $3.52 \pm 0.71^{* *}$ & $5.43 \pm 1.03^{\mathrm{ns}}$ & $4.54 \pm 0.84^{\mathrm{ns}}$ \\
AChE liver $^{\mathrm{c}}$ & $6.85 \pm 0.51$ & $4.23 \pm 0.89^{* * *}$ & $7.28 \pm 0.40^{\mathrm{ns}}$ & $6.36 \pm 0.31^{\mathrm{ns}}$ \\
\hline
\end{tabular}

Specific activity of rat liver a GST: $\mu$ mole $\mathrm{mL}^{-1} \mathrm{~min}^{-1} \mathrm{mg}^{-1}$ protein; ${ }^{\mathrm{b}} \mathrm{SOD}$ activity: one unit of the enzyme activity has been expressed as $50 \%$ inhibition of autooxidation of pyrogallol $\mathrm{min}^{-1} \mathrm{mg}^{-1}$; ${ }^{b}$ catalase activity: micromoles of $\mathrm{H}_{2} \mathrm{O}_{2}$ decomposed per $\mathrm{min}^{-1} \mathrm{mg}^{-1}$; ${ }^{\mathrm{c}}$ specific activity of liver AChE $=$ $\mu$ mole $\mathrm{mL}^{-1} \mathrm{~min}^{-1} \mathrm{mg}^{-1}$. Each data set is presented as Mean $\pm \mathrm{SD}$. The signs $*, * *$, and $* * *$ indicate the data significant at $p<0.05, p<0.01$, and $p<0.005$, respectively, as compared to the control group.

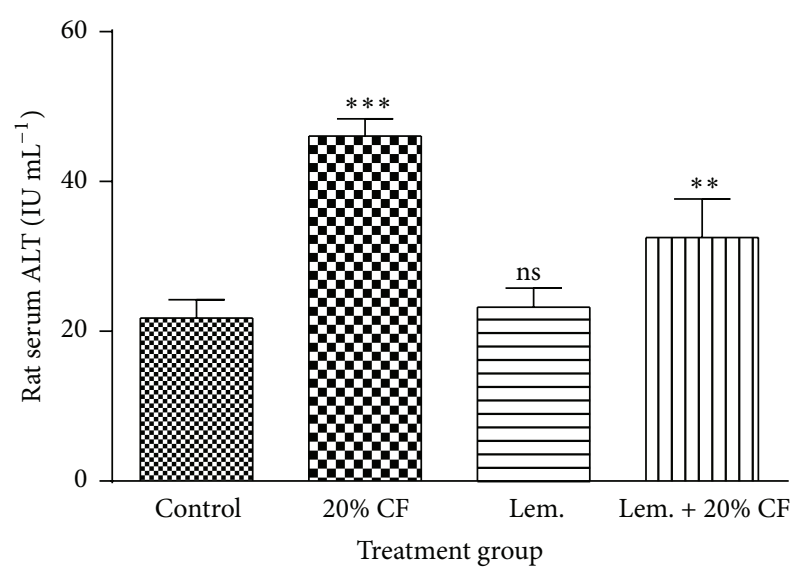

FIGURE 5: Effect of CF on the activity of ALT in serum of rat and amelioration by C. limon fruit extract. Control: control group treated with $0.5 \mathrm{~mL}$ groundnut oil; $20 \% \mathrm{CF}$ : three subacute oral doses $\left(1.6 \mathrm{mg} \mathrm{Kg}^{-1}\right.$ bwt equivalent to $20 \% \mathrm{LD}_{50}$ ) of CF. C. limon: the rats treated with $0.5 \mathrm{~mL} \mathrm{C}$. limon fruit extract three times at the intervals of 24 hours. Citrus $+20 \%$ CF refer to the experimental animals group which received $0.5 \mathrm{~mL} \mathrm{C}$. limon fruit extract $30 \mathrm{~min}$ prior to the treatment of rats with $\mathrm{CF}\left(1.6 \mathrm{mg} \mathrm{Kg}^{-1}\right.$ bwt $)$. All the treatments were given as three-time oral doses at the interval of $24 \mathrm{~h}$ and experiments were carried out up to three days. The animals were sacrificed after $24 \mathrm{~h}$ from the last dose of treatment. ALT activity was determined as described in Materials and Methods. The unit of enzyme activity was expressed as IU mL $\mathrm{m}^{-1}$. The values were expressed as Mean $\pm \mathrm{SD}$; $n=5$, where $n$ is number of determinations. The signs $* *$ and $* * *$ indicate the data significant at $p<0.01$ and $p<0.005$, respectively, as compared to the control group.

the $C$. limon fruit extract before carbofuran treatment in the present study showed relatively lower impact of carbofuran, which reflects ameliorative property of the fruit extract. It may be due to the presence of antioxidative compounds in this citrus fruit. Since C. limon is reported to contain plenty of vitamin $\mathrm{C}$, the antioxidative effect exerted by the fruit extract may be due to the presence of this compound. This notion is strongly supported by a recent report on the chemical analysis of C. limon fruit extract components showing antioxidant capacity of four Tunisian citrus varieties [43].

The results of the present investigation have demonstrated the enhancement of total cholesterol and significant decrease in the level of HDL in the serum of rat treated with carbofuran. These results are in agreement with that reported

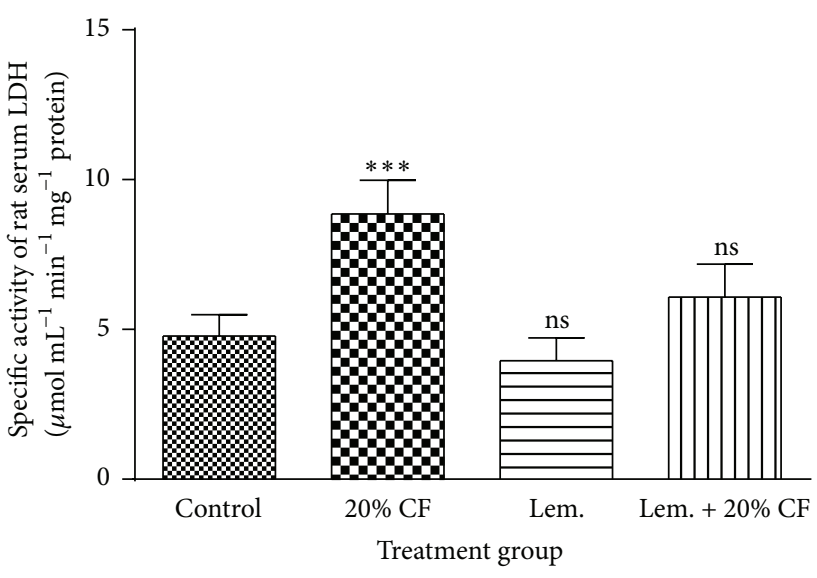

FIGURE 6: Effect of CF on the activity of LDH in liver of rat and amelioration by C. limon fruit extract. Control: control group treated with $0.5 \mathrm{~mL}$ groundnut oil; $20 \% \mathrm{CF}$ : three subacute oral doses (1.6 $\mathrm{mg} \mathrm{Kg}^{-1}$ bwt equivalent to $20 \% \mathrm{LD}_{50}$ ) of CF. Citrus: the rats treated with $0.5 \mathrm{~mL} \mathrm{C.} \mathrm{limon} \mathrm{fruit} \mathrm{extract} \mathrm{three} \mathrm{times} \mathrm{at} \mathrm{the} \mathrm{intervals}$ of $24 \mathrm{~h}$. Citrus $+20 \%$ CF refer to the experimental animals group which received $0.5 \mathrm{~mL} \mathrm{C}$. limon fruit extract $30 \mathrm{~min}$ prior to the treatment of rats with $\mathrm{CF}\left(1.6 \mathrm{mg} \mathrm{Kg}^{-1}\right.$ bwt $)$. All the treatments were given as three-time oral doses at the interval of $24 \mathrm{~h}$ and experiments were carried out up to three days. The animals were sacrificed after $24 \mathrm{~h}$ from the last dose of treatment. LDH activity was determined as described in Materials and Methods. The unit of enzyme activity was expressed as $\mu$ mole $\mathrm{mL}^{-1} \mathrm{~min}^{-1} \mathrm{mg}^{-1}$. The values were expressed as Mean $\pm \mathrm{SD} ; n=5$, where $n$ is number of determinations. The sign $(* * *)$ indicates values significantly different from control at $p<0.005$.

by Rai et al. [44]. They have explained that the elevation of total cholesterol under the influence of intraperitoneal administration of carbofuran may be due to the stimulation of catecholamines, which stimulate lipolysis and increase fatty acid production. The results of the present study have indicated that the treatment of rat with $C$. limon fruit extract before the carbofuran treatment reduced the rise in the level of total cholesterol. The ameliorative property of $C$. limon fruit extract may be due to the presence of total flavonoids, hesperidin, ascorbic acid, and pectin contained in it as reported by other workers [20]. The hesperidin probably influences the inhibition of HMG-CoA, which may lead to the reduction of cholesterol level in the serum of rat $[20]$. 


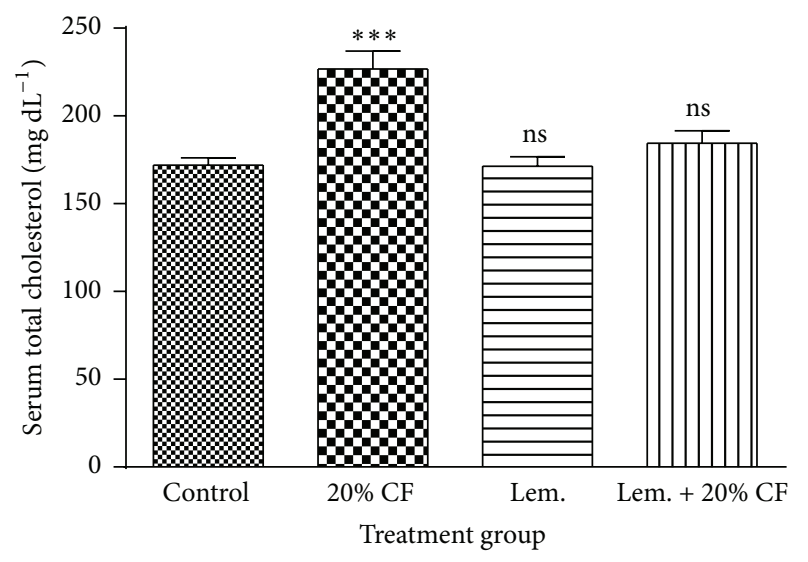

Figure 7: Effect of CF on the level of serum total cholesterol and amelioration by $C$. limon fruit extract. Control: control group treated with $0.5 \mathrm{~mL}$ groundnut oil; $20 \% \mathrm{CF}$ : three subacute oral doses $\left(1.6 \mathrm{mg} \mathrm{Kg}^{-1}\right.$ bwt equivalent to $20 \% \mathrm{LD}_{50}$ ) of CF. C. limon: the rats treated with $0.5 \mathrm{~mL} \mathrm{C}$. limon fruit extract three times at the intervals of 24 h. C. limon $+20 \%$ CF refer to the experimental animals group which received $0.5 \mathrm{~mL} \mathrm{C}$. limon fruit extract $30 \mathrm{~min}$ prior to the treatment of rats with $\mathrm{CF}\left(1.6 \mathrm{mg} \mathrm{Kg}^{-1} \mathrm{bwt}\right)$. All the treatments were given as three-time oral doses at the interval of $24 \mathrm{~h}$ and experiments were carried out up to three days. The animals were sacrificed after $24 \mathrm{~h}$ from the last dose of treatment. Level of total cholesterol was determined as described in Materials and Methods. The unit of level of total cholesterol is $\mathrm{mg} \mathrm{dL}^{-1}$. The values were expressed as Mean \pm $\mathrm{SD} ; n=5$, where $n$ is number of determinations. The sign $(* * *)$ indicates values significantly different from control at $p<0.005$.

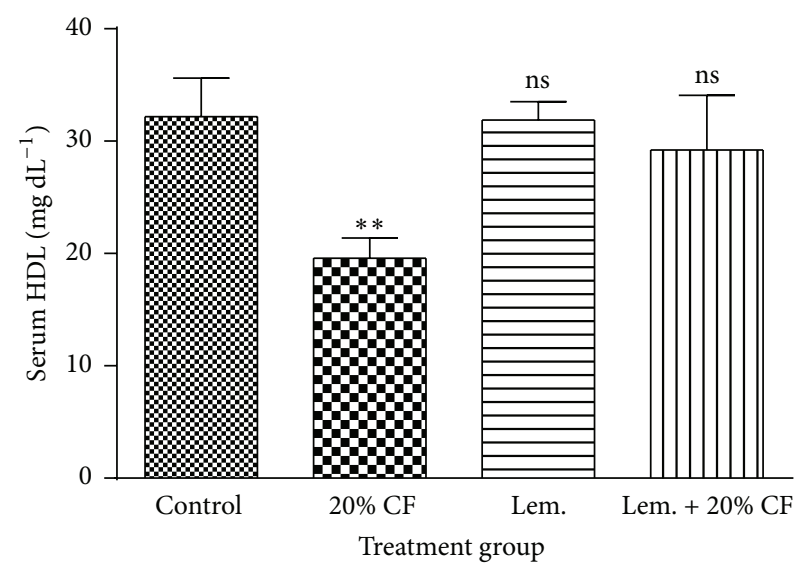

FIgURE 8: Effect of CF on the level of serum HDL and amelioration by $C$. limon fruit extract. Control: control group treated with $0.5 \mathrm{~mL}$ groundnut oil; $20 \%$ CF: three subacute oral doses $\left(1.6 \mathrm{mg} \mathrm{Kg}^{-1}\right.$ bwt equivalent to $20 \% \mathrm{LD}_{50}$ ) of CF. C. limon: the rats treated with $0.5 \mathrm{~mL}$ C. limon fruit extract three times at the intervals of 24 hours. $C$. limon $+20 \%$ CF refer to the experimental animals group which received $0.5 \mathrm{~mL} \mathrm{C.} \mathrm{limon} \mathrm{fruit} \mathrm{extract} 30 \mathrm{~min}$ prior to the treatment of rats with $\mathrm{CF}\left(1.6 \mathrm{mg} \mathrm{Kg}^{-1} \mathrm{bwt}\right)$. All the treatments were given as three-time oral doses at the interval of $24 \mathrm{~h}$ and experiments were carried out up to three days. The animals were sacrificed after $24 \mathrm{~h}$ from the last dose of treatment. Level of HDL was determined as described in Materials and Methods. The unit of level of total cholesterol is $\mathrm{mg} \mathrm{dL}^{-1}$. The values were expressed as Mean $\pm \mathrm{SD}$; $n=5$, where $n$ is number of determinations. The sign $(* *)$ indicates values significantly different from control at $p<0.01$.

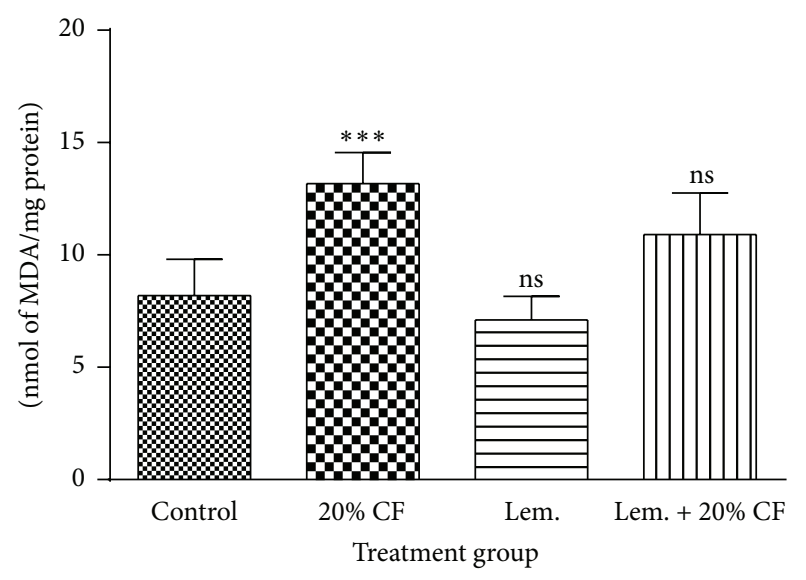

FIGURE 9: Effect of CF on the level of liver MDA and amelioration by C. limon fruit extract. Control: control group treated with $0.5 \mathrm{~mL}$ groundnut oil; $20 \%$ CF: three subacute oral doses $\left(1.6 \mathrm{mg} \mathrm{Kg}^{-1}\right.$ bwt equivalent to $20 \% \mathrm{LD}_{50}$ ) of CF. C. limon: the rats treated with $0.5 \mathrm{~mL}$ C. limon fruit extract three times at the intervals of 24 hours. C. limon $+20 \%$ CF refer to the experimental animals group which received $0.5 \mathrm{~mL} \mathrm{C}$. limon fruit extract $30 \mathrm{~min}$ prior to the treatment of rats with CF (1.6 mg Kg$\left.{ }^{-1} \mathrm{bwt}\right)$. All the treatments were given as threetime oral doses at the interval of $24 \mathrm{~h}$ and experiments were carried out up to three days. The animals were sacrificed after $24 \mathrm{~h}$ from the last dose of treatment. Level of MDA was determined as described in Materials and Methods. The unit of level of MDA is nmoles of $\mathrm{MDA} / \mathrm{mg}$ protein. The values were expressed as Mean $\pm \mathrm{SD} ; n=$ 5 , where $n$ is number of determinations. The $\operatorname{sign}(* * *)$ indicates values significantly different from control at $p<0.005$.

Glutathione, a tripeptide, works as a nonenzymatic antioxidant. It is involved in elimination of endogenously produced Reactive Oxygen Species (ROS) and Nitrogen Species (RNS) [45]. In the present study, CF treatment was found to enhance the level of GSH. Similar results have been presented by Kaur and Sandhir [14] in the liver and kidney of rats upon chronic exposure to CF. Though there is no report suggesting protection of GSH by lemon juice in mammalian systems, supplementation of cysteine has been reported to enhance synthesis of glutathione, thereby reducing pesticide induced toxicity via oxidative stress [45].

At the normal physiological conditions, the catalytic function of SOD generates $\mathrm{H}_{2} \mathrm{O}_{2}$ by the dismutation of $\mathrm{O}_{2}{ }^{\cdot}$ (superoxide radical) which is degraded into $\mathrm{H}_{2} \mathrm{O}$ and molecular oxygen via a chemical reaction catalyzed by CAT. So any perturbations taking place in the activities of these enzymes directly influence the redox system of the body and finally lead to oxidative stress [18]. In the present study, the reduction in the activities of these enzymes resulted in the accumulation of increased amount of ROS as confirmed by the elevation of the level of MDA in the rat liver tissues. Similar to these observations, the reduced activities of these antioxidant enzymes in rat liver exposed to CF $\left(0.6 \mathrm{mg} \mathrm{Kg}^{-1}\right.$ body weight) for longer treatment durations (1 and 2 months) have been reported [18]. The reduction in the activities of these enzymes has also been demonstrated in the kidney of rats exposed to carbofuran $\left(1 \mathrm{mg} \mathrm{Kg}^{-1}\right.$ body weight $)$ for longer duration (28 days) [10]. However, in contrast to these 


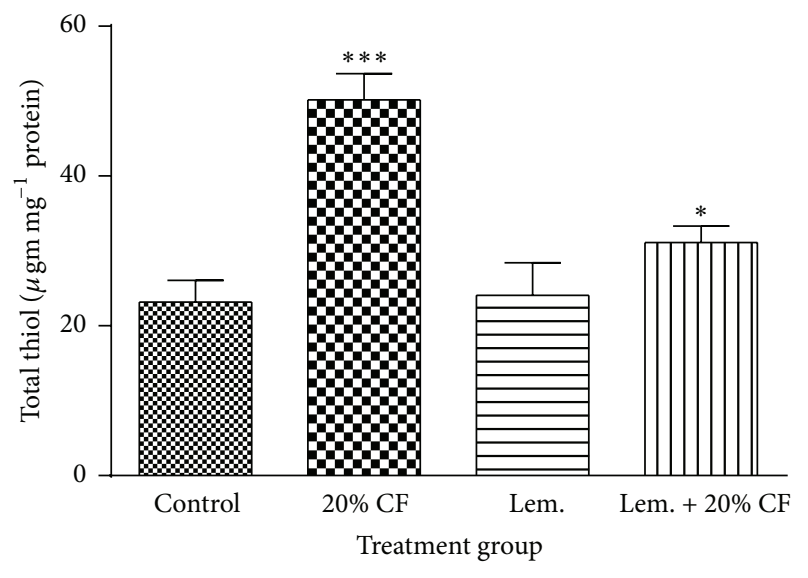

FIGURE 10: Effect of CF on the level of liver total thiol and amelioration by C. limon fruit extract. Control: control group treated with $0.5 \mathrm{~mL}$ groundnut oil; $20 \% \mathrm{CF}$ : three subacute oral doses (1.6 $\mathrm{mg} \mathrm{Kg}^{-1}$ bwt equivalent to $20 \% \mathrm{LD}_{50}$ ) of CF. C. limon: the rats treated with $0.5 \mathrm{~mL}$ C. limon fruit extract three times at the intervals of $24 \mathrm{~h}$. C. limon $+20 \% \mathrm{CF}$ refer to the experimental animals group which received $0.5 \mathrm{~mL} \mathrm{C}$. limon fruit extract $30 \mathrm{~min}$ prior to the treatment of rats with $\mathrm{CF}\left(1.6 \mathrm{mg} \mathrm{Kg}^{-1}\right.$ bwt $)$. All the treatments were given as three-time oral doses at the interval of $24 \mathrm{~h}$ and experiments were carried out up to three days. The animals were sacrificed after $24 \mathrm{~h}$ from the last dose of treatment. Level of liver total thiol was determined as described in Materials and Methods. The unit of level of total thiol is $\mu \mathrm{g} \mathrm{mg}^{-1}$ protein. The values were expressed as Mean $\pm \mathrm{SD} ; n=5$, where $n$ is number of determinations. The signs $*$ and $* * *$ indicate values significantly different from control at $p<0.05$ and $p<0.005$, respectively.

findings a single i.p. dose of $10 \% \mathrm{LD}_{50}$ of carbofuran has been reported to enhance the activity of CAT [17]. The restoration of the activity of these enzymes in the present investigation to near normal level due to introduction of $C$. limon fruit extract in the pesticide treated animals suggested the antioxidative and ameliorative potential.

Glutathione-S-transferase (GST) is a Phase II detoxifying enzyme which catalyzes the conjugation of the tripeptide glutathione to electrophilic centers of lipophilic compounds in such a way that the solubility of such compounds increases due to the binding of tripeptide glutathione [46]. The inhibition in GST activity in carbofuran treated rat liver as observed in this study may adversely influence the cascade of Phase II detoxifying reactions in rat liver. The reduction in the level of GST activity has also been reported in rat brain [25] and erythrocytes [26]. In contrast, the acute and chronic doses of carbofuran have been reported to cause elevation in GST activity in rat [10]. The recovery of GST in carbofuran treated rat by $C$. limon fruit extract has been reported by other workers as well, which has been attributed to the presence of limonin and nomilin in the $C$. limon fruit extract which are known as inducers of GST activity [47].

The primary function of $\mathrm{AChE}$ is to maintain homeostasis of acetylcholine (ACh) in the central as well as peripheral nervous system because it catalyzes hydrolysis of released neurotransmitter ACh [48]. Carbofuran causes inhibition of acetylcholinesterase (AChE) along with other nonspecific

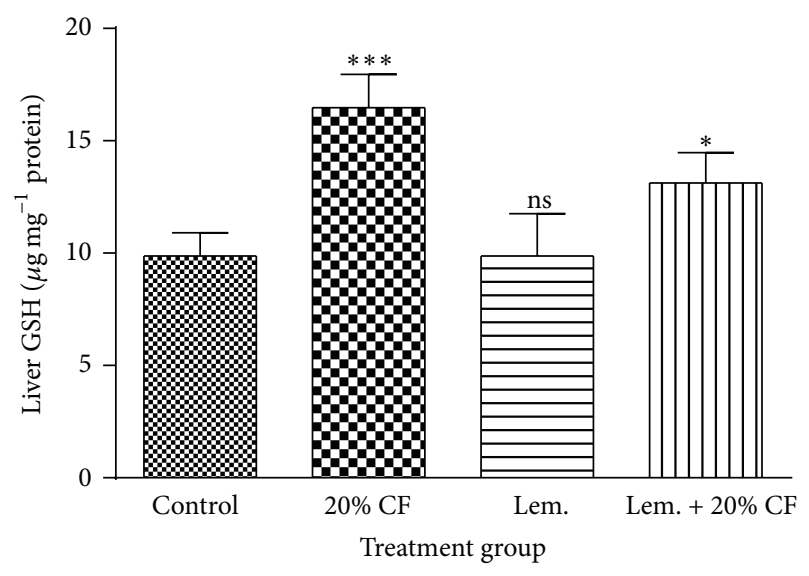

FIGURE 11: Effect of CF on the level of liver GSH and amelioration by C. limon fruit extract. Control: control group treated with $0.5 \mathrm{~mL}$ groundnut oil; $20 \%$ CF: three subacute oral doses $\left(1.6 \mathrm{mg} \mathrm{Kg}^{-1}\right.$ bwt equivalent to $20 \% \mathrm{LD}_{50}$ ) of CF. C. limon: the rats treated with $0.5 \mathrm{~mL}$ C. limon fruit extract three times at the intervals of $24 \mathrm{~h}$. C. limon $+20 \%$ CF refer to the experimental animals group which received $0.5 \mathrm{~mL} \mathrm{C}$. limon fruit extract $30 \mathrm{~min}$ prior to the treatment of rats with $\mathrm{CF}\left(1.6 \mathrm{mg} \mathrm{Kg}^{-1}\right.$ bwt). All the treatments were given as threetime oral doses at the interval of $24 \mathrm{~h}$ and experiments were carried out up to three days. The animals were sacrificed after $24 \mathrm{~h}$ from the last dose of treatment. Level of liver GSH was determined as described in Materials and Methods. The unit of level of GSH is $\mu \mathrm{g} \mathrm{mg}^{-1}$ protein. The values were expressed as Mean $\pm \mathrm{SD} ; n=5$, where $n$ is number of determinations. The signs $*$ and $* * *$ indicate values significantly different from control at $p<0.05$ and $p<0.005$.

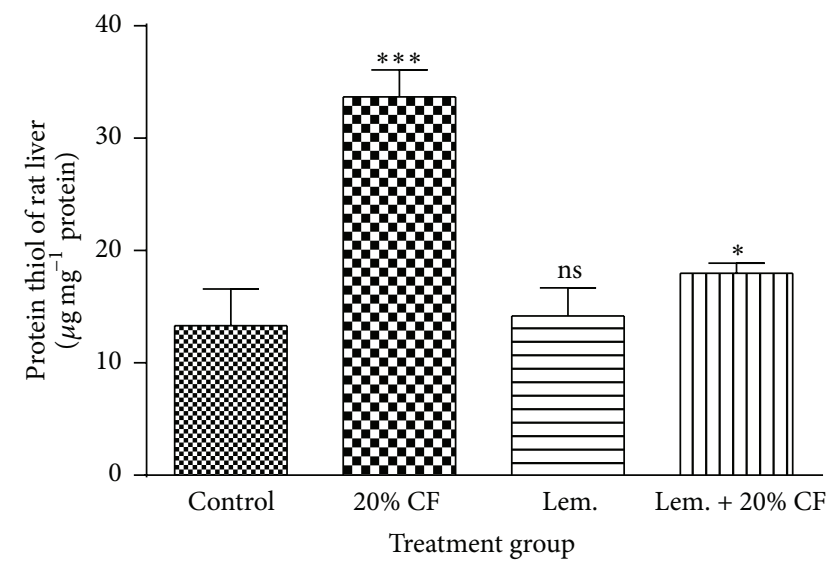

FIgURE 12: Effect of CF on the level of liver protein thiol and amelioration by C. limon fruit extract. Control: control group treated with $0.5 \mathrm{~mL}$ groundnut oil; $20 \% \mathrm{CF}$ : three subacute oral doses (1.6 mg Kg ${ }^{-1}$ bwt equivalent to $20 \% \mathrm{LD}_{50}$ ) of CF. C. limon: the rats treated with $0.5 \mathrm{~mL} \mathrm{C}$. limon fruit extract three times at the intervals of 24 hours. C. limon $+20 \%$ CF refer to the experimental animals group which received $0.5 \mathrm{~mL} \mathrm{C}$. limon fruit extract $30 \mathrm{~min}$ prior to the treatment of rats with $\mathrm{CF}$ ( $\left.1.6 \mathrm{mg} \mathrm{Kg}^{-1} \mathrm{bwt}\right)$. All the treatments were given as three-time oral doses at the interval of $24 \mathrm{~h}$ and experiments were carried out up to three days. The animals were sacrificed after $24 \mathrm{~h}$ from the last dose of treatment. Level of liver protein thiol was determined as described in Materials and Methods. The unit of level of protein thiol is $\mu \mathrm{g} \mathrm{mg}^{-1}$ protein. The values were expressed as Mean $\pm \mathrm{SD} ; n=5$, where $n$ is number of determinations. The signs $*$ and $* * *$ indicate values significantly different from control at $p<0.05$ and $p<0.005$, respectively. 
serine containing enzymes such as carboxylesterases (CarbEs) and butyrylcholinesterases (BuChE) [11]. In the present study the inhibition of AChE due to carbofuran intoxication was recovered with the administration of $C$. limon fruit extract. Since AChE is a membrane bound enzyme, it is possible that the free radicals generated under pesticide stress may cause lipid peroxidation of the lipid bilayer of the membrane and hence may contribute in the reduction of AChE in rat. The antioxidants (vitamin C, flavonoids) present in the $C$. limon fruit extract may help quench the free radicals and thus offer protection to the enzyme. Earlier, the pretreatment of rats with another plant extract isolated from Cynodon dactylon has been reported to protect the brain of rats from carbofuran mediated toxicity [25].

\section{Conclusion}

The results of the present study have indicated that carbofuran treatment has resulted in generation of oxidative stress in rat liver. It has caused significant alterations in the levels of redox indices (both enzymatic and nonenzymatic), total cholesterol, and HDL as well as the activities of transaminases, and $\mathrm{AChE}$ in the rat liver and serum. The pretreatment of rats with $C$. limon fruit extract was found to significantly mimic the adverse effect of carbofuran, thereby protecting the animal from the pesticide induced oxidative stress mediated injury. The ameliorating effect of $C$. limon fruit extract was observed to be noteworthy. Since the pesticides induced free radical mediated tissue damage is the underlying mechanism of the toxicity of these chemicals, different antioxidants including vitamin $\mathrm{C}$ present in the $C$. limon fruit extract may be playing ameliorating role by neutralizing the ROS and RNS generated in body tissues. The results of the present study suggest that $C$. limon fruit extract may be utilized in suitable management of the pesticide intoxication in association with relevant therapeutics.

\section{Conflict of Interests}

The authors declare that they have no conflict of interests regarding the publication of this paper.

\section{Acknowledgments}

The authors Sunil Kumar Jaiswal and Vivek K. Gupta thank University Grants Commission (UGC), New Delhi, for financial support in the form of a research fellowship. Nikhat J. Siddiqi would like to thank the Research Center, Center for Scientific and Medical Female Colleges, King Saud University, Riyadh, for the financial support.

\section{References}

[1] F. M. El-Demerdash, "Oxidative stress and hepatotoxicity induced by synthetic pyrethroids-organophosphate insecticides mixture in rat," Journal of Environmental Science and Health, Part C: Environmental Carcinogenesis and Ecotoxicology Reviews, vol. 29, no. 2, pp. 145-158, 2011.

[2] S. A. M. Zaahkouk, E. G. E. Helal, T. E. I. Abd-Rabo, and S. Z. A. Rashed, "Carbamate toxicity and protective effect of Vitamin
A and E on some biochemical aspects of male albino rats," Egyptian Journal of Hospital Medicine, vol. 1, pp. 60-77, 2000.

[3] V. V. Padma, P. Sowmya, T. A. Felix, R. Baskaran, and P. Poornima, "Protective effect of gallic acid against lindane induced toxicity in experimental rats," Food and Chemical Toxicology, vol. 49, no. 4, pp. 991-998, 2011.

[4] R. K. Loch-Caruso, K. A. Criswell, C. M. Grindatti, and K. A. Brant, "Sustained inhibition of rat myometrial gap junctions and contractions by lindane," Reproductive Biology and Endocrinology, vol. 1, article 62, 2003.

[5] M.-P. Sauviat, A. Colas, and N. Pages, "Does lindane (gammahexachlorocyclohexane) increase the rapid delayed rectifier outward $\mathrm{K}^{+}$current (IKr) in frog atrial myocytes?” BMC Pharmacology, vol. 2, article 15, 2002.

[6] T. R. Fukuto, "Mechanism of action of organophosphorus and carbamate insecticides," Environmental Health Perspectives, vol. 87, pp. 245-254, 1990.

[7] D. Milatovic, R. C. Gupta, and M. Aschner, "Anticholinesterase toxicity and oxidative stress," The Scientific World Journal, vol. 6, pp. 295-310, 2006.

[8] S. Padilla, R. S. Marshall, D. L. Hunter, and A. Lowit, "Time course of cholinesterase inhibition in adult rats treated acutely with carbaryl, carbofuran, formetanate, methomyl, methiocarb, oxamyl or propoxur," Toxicology and Applied Pharmacology, vol. 219, no. 2-3, pp. 202-209, 2007.

[9] R. M. Whyatt, D. B. Barr, D. E. Camann et al., "Contemporaryuse pesticide in personal air samples during pregnancy and blood samples at delivery among urban minority mothers and newborns," Environmental Health Perspectives, vol. 111, no. 5, pp. 749-756, 2003.

[10] B. Kaur, A. Khera, and R. Sandhir, "Attenuation of cellular antioxidant defense mechanisms in kidney of rats intoxicated with carbofuran," Journal of Biochemical and Molecular Toxicology, vol. 26, no. 10, pp. 393-398, 2012.

[11] R. C. Gupta, "Carbofuran toxicity", Journal of Toxicology and Environmental Health, vol. 43, no. 4, pp. 383-418, 1994.

[12] S. K. Jaiswal, N. J. Siddiqi, and B. Sharma, "Carbofuran imbalances of the redox status in rat brain: amelioration by vitamin C," Journal of Biochemistry Research, vol. 1, no. 4, pp. 36-43, 2013.

[13] S. K. Jaiswal, N. J. Siddiqi, and B. Sharma, "Carbofuran induced oxidative stress in rat heart: ameliorative effect of vitamin C," ISRN Oxidative Medicine, vol. 2013, Article ID 824102, 10 pages, 2013.

[14] M. Kaur and R. Sandhir, "Comparative effects of acute and chronic carbofuran exposure on oxidative stress and drugmetabolizing enzymes in liver," Drug and Chemical Toxicology, vol. 29, no. 4, pp. 415-421, 2006.

[15] A. Agrawal and B. Sharma, "Pesticides induced oxidative stress in mammalian systems," International Journal of Biological and Medical Research, vol. 1, no. 3, pp. 90-104, 2010.

[16] H. M. Abdou, H. M. Hussien, and M. I. Yousef, "Deleterious effects of cypermethrin on rat liver and kidney: protective role of sesame oil," Journal of Environmental Science and HealthPart B: Pesticides, Food Contaminants, and Agricultural Wastes, vol. 47, no. 4, pp. 306-314, 2012.

[17] D. K. Rai and B. Sharma, "Carbofuran-induced oxidative stress in mammalian brain," Molecular Biotechnology, vol. 37, no. 1, pp. 66-71, 2007.

[18] S. Srinivasan and L. Pari, "Ameliorative effect of diosmin, a citrus flavonoid against streptozotocin-nicotinamide generated 
oxidative stress induced diabetic rats," Chemico-Biological Interactions, vol. 195, no. 1, pp. 43-51, 2012.

[19] L. M. L. Campêlo, A. A. C. de Almeida, R. L. M. de Freitas et al., "Antioxidant and antinociceptive effects of Citrus limon essential oil in mice," Journal of Biomedicine and Biotechnology, vol. 2011, Article ID 678673, 8 pages, 2011.

[20] A. Trovato, M. T. Monforte, R. Barbera, A. Rossitto, E. M. Galati, and A. M. Forestieri, "Effects of fruit juices of Citrus sinensis L. and Citrus limon L. on experimental hypercholesterolemia in the rat," Phytomedicine, vol. 2, no. 3, pp. 221-227, 1996.

[21] R. Lichtenthäler and F. Marx, "Total oxidant scavenging capacities of common European fruit and vegetable juices," Journal of Agricultural and Food Chemistry, vol. 53, no. 1, pp. 103-110, 2005.

[22] A. M. Pisoschi, A. F. Danet, and S. Kalinowski, "Ascorbic acid determination in commercial fruit juice samples by cyclic voltammetry," Journal of Automated Methods and Management in Chemistry, vol. 2008, Article ID 937651, 8 pages, 2008.

[23] J. E. Andrade and J. R. Burgess, "Effect of the citrus flavanone naringenin on oxidative stress in rats," Journal of Agricultural and Food Chemistry, vol. 55, no. 6, pp. 2142-2148, 2007.

[24] D. K. Rai, P. K. Rai, G. Watal, and B. Sharma, "The Cynodon dactylon extract help improve anticholinesterase effects and oxidative stress caused by carbofuran in rat brain," Toxicologic Pathology, vol. 38, no. 1, abstract P-45, pp. E1-E6, 2010.

[25] D. K. Rai, R. K. Sharma, P. K. Rai, G. Watal, and B. Sharma, "Role of aqueous extract of Cynodon dactylon in prevention of carbofuran-induced oxidative stress and acetylcholinesterase inhibition in rat brain," Cellular and Molecular Biology, vol. 57, no. 1, pp. 135-142, 2011.

[26] D. K. Rai, P. K. Rai, S. I. Rizvi, G. Watal, and B. Sharma, "Carbofuran-induced toxicity in rats: protective role of vitamin C," Experimental and Toxicologic Pathology, vol. 61, no. 6, pp. 531$535,2009$.

[27] G. L. Ellman, K. D. Courtney, V. Andres Jr., and R. M. Feather-Stone, "A new and rapid colorimetric determination of acetylcholinesterase activity," Biochemical Pharmacology, vol. 7, no. 2, pp. 88-95, 1961.

[28] B. L. Horecker and A. Kornberg, "The extinction coefficient of the reduced band of pyridine nucleotides," Journal of Biological Chemistry, vol. 175, pp. 385-390, 1948.

[29] S. Reitman and S. Frankel, "A colorimetric method for the determination of serum glutamic oxalacetic and glutamic pyruvic transaminases," American Journal of Clinical Pathology, vol. 28, no. 1, pp. 56-63, 1957.

[30] A. Zlatkis, B. Zak, and A. J. Boyle, "A new method for the direct determination of serum cholesterol," The Journal of Laboratory and Clinical Medicine, vol. 41, no. 3, pp. 486-492, 1953.

[31] M. F. Lopes Virella, P. Stone, S. Ellis, and J. A. Colwell, "Cholesterol determination in high density lipoproteins separated by three different methods," Clinical Chemistry, vol. 23, no. 5, pp. 882-884, 1977.

[32] W. G. Niehaus Jr. and B. Samuelsson, "Formation of malonaldehyde from phospholipid arachidonate during microsomal lipid peroxidation.", European Journal of Biochemistry, vol. 6, no. 1, pp. 126-130, 1968.

[33] S. Marklund and G. Marklund, "Involvement of the superoxide anion radical in the autoxidation of pyrogallol and a convenient assay for superoxide dismutase," European Journal of Biochemistry, vol. 47, no. 3, pp. 469-474, 1974.
[34] R. F. Beers Jr. and I. W. Sizer, "A spectrophotometric method for measuring the breakdown of hydrogen peroxide by catalase," The Journal of Biological Chemistry, vol. 195, no. 1, pp. 133-140, 1952.

[35] W. H. Habig, M. J. Pabst, and W. B. Jakoby, "Glutathione S-transferases. The first enzymatic step in mercapturic acid formation," The Journal of Biological Chemistry, vol. 249, no. 22, pp. 71307139, 1974.

[36] G. L. Ellman, "Tissue sulfhydryl groups," Archives of Biochemistry and Biophysics, vol. 82, no. 1, pp. 70-77, 1959.

[37] J. Sedlak and R. H. Lindsay, "Estimation of total, proteinbound, and nonprotein sulfhydryl groups in tissue with Ellman's reagent," Analytical Biochemistry, vol. 25, no. 1, pp. 192-205, 1968.

[38] O. H. Lowry, N. J. Rosebrough, A. L. Farr, and R. J. Randel, "Protein measurement with folin-phenol reagent," Journal of Biological Chemistry, vol. 193, no. 1, pp. 265-275, 1951.

[39] A. G. Lee, J. East, and P. Balagaug, "Interactions of insecticides with biological membranes," Pesticide Science, vol. 32, pp. 317327, 1991.

[40] R. C. Gupta, J. T. Goad, and W. L. Kadel, "In vivo alterations in lactate dehydrogenase (LDH) and $\mathrm{LDH}$ isoenzymes patterns by acute carbofuran intoxication," Archives of Environmental Contamination and Toxicology, vol. 21, no. 2, pp. 263-269, 1991.

[41] D. M. Soderlund, J. M. Clark, L. P. Sheets et al., "Mechanisms of pyrethroid neurotoxicity: implications for cumulative risk assessment," Toxicology, vol. 171, no. 1, pp. 3-59, 2002.

[42] H. Fetoui, E. M. Garoui, and N. Zeghal, "Lambda-cyhalothrininduced biochemical and histopathological changes in the liver of rats: ameliorative effect of ascorbic acid," Experimental and Toxicologic Pathology, vol. 61, no. 3, pp. 189-196, 2009.

[43] M. S. Tounsi, W. A. Wannes, I. Ouerghemmi et al., "Juice components and antioxidant capacity of four Tunisian Citrus varieties," Journal of the Science of Food and Agriculture, vol. 91, no. 1, pp. 142-151, 2011.

[44] D. K. Rai, P. K. Rai, A. Gupta, G. Watal, and B. Sharma, "Cartap and carbofuran induced alterations in serum lipid profile of Wistar rats," Indian Journal of Clinical Biochemistry, vol. 24, no. 2, pp. 198-201, 2009.

[45] V. I. Lushchak, "Glutathione homeostasis and functions: potential targets for medical interventions," Journal of Amino Acids, vol. 2012, Article ID 736837, 26 pages, 2012.

[46] J. G. Vontas, G. J. Small, and J. Hemingway, "Glutathione Stransferases as antioxidant defence agents confer pyrethroid resistance in Nilaparvata lugens," Biochemical Journal, vol. 357, no. 1, pp. 65-72, 2001.

[47] C. Kelly, C. Jewell, and N. M. O’Brien, “The effect of dietary supplementation with the citrus limonoids, limonin and nomilin on xenobiotic-metabolizing enzymes in the liver and small intestine of the rat," Nutrition Research, vol. 23, no. 5, pp. 681690, 2003.

[48] A. Dobbertin, A. Hrabovska, K. Dembele et al., "Targeting of acetylcholinesterase in neurons in vivo: a dual processing function for the proline-rich membrane anchor subunit and the attachment domain on the catalytic subunit," The Journal of Neuroscience, vol. 29, no. 14, pp. 4519-4530, 2009. 

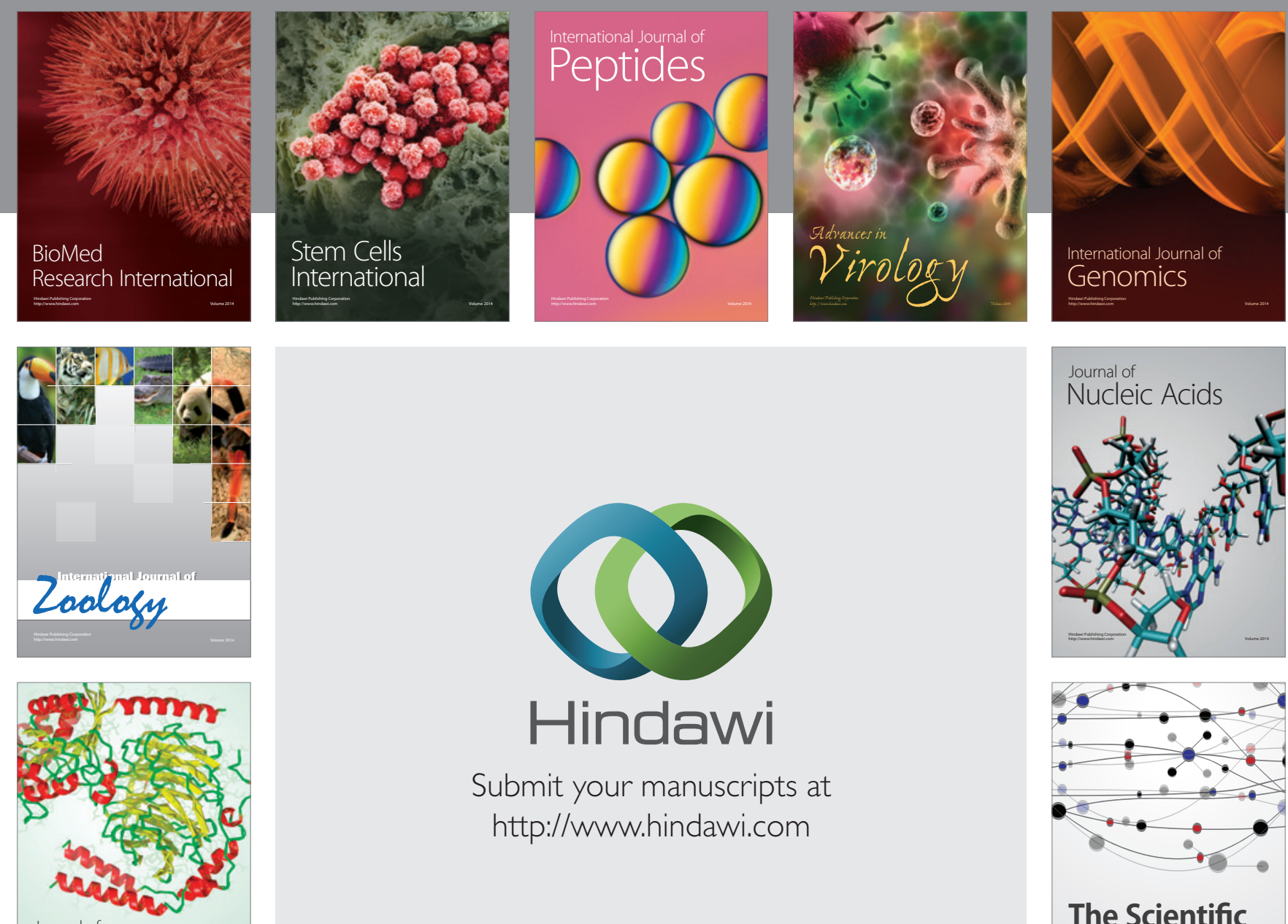

Submit your manuscripts at

http://www.hindawi.com

Journal of
Signal Transduction
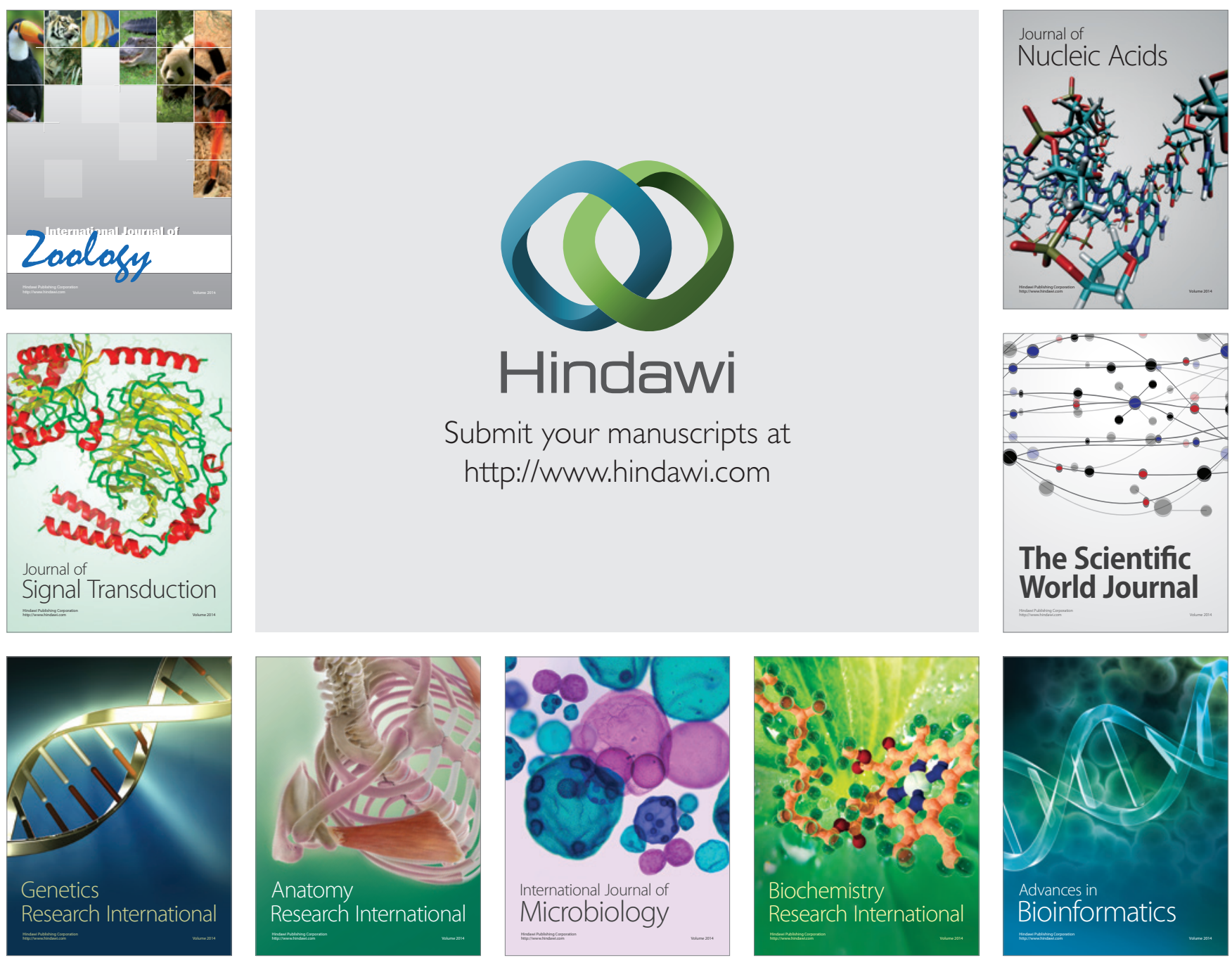

The Scientific World Journal
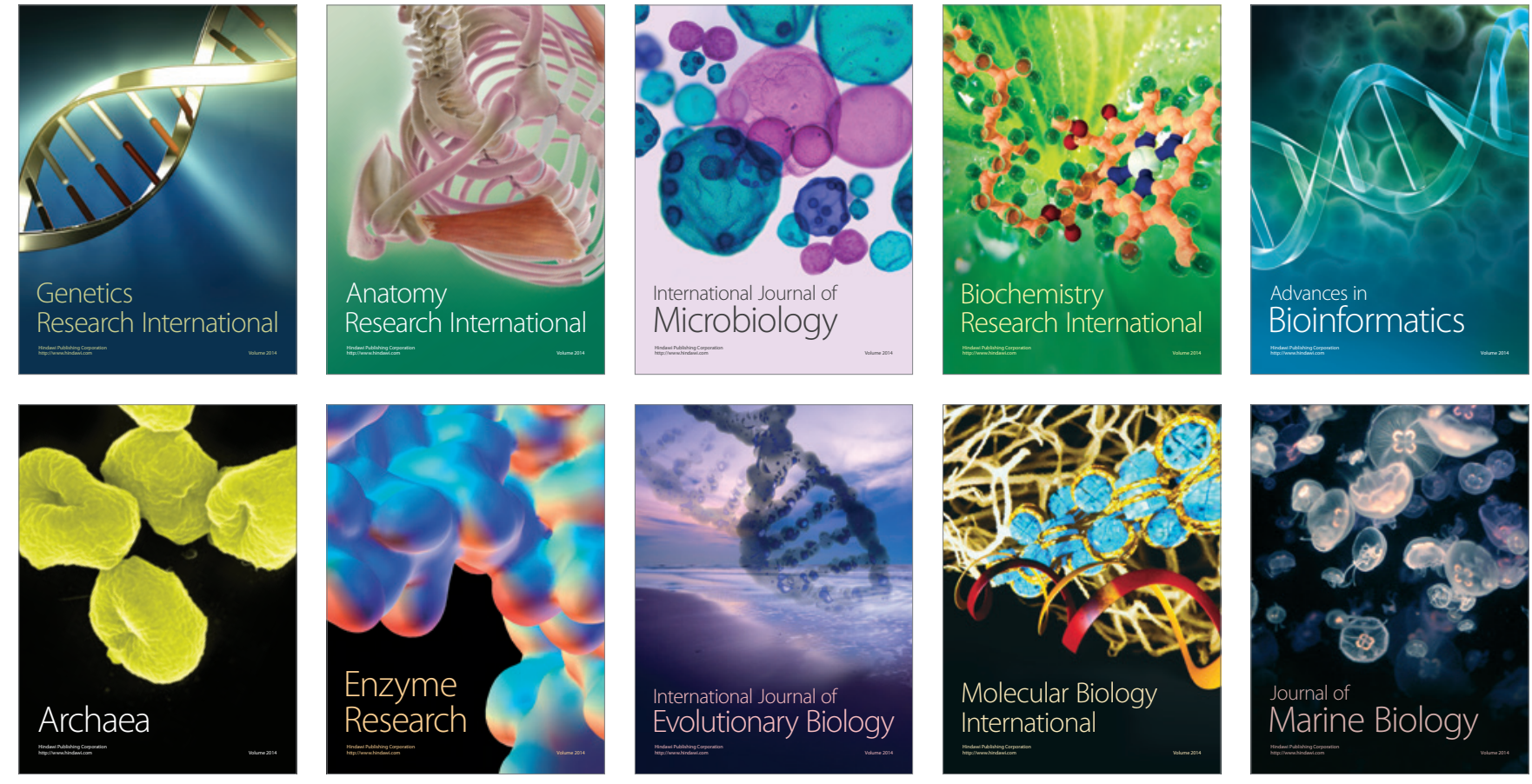